\title{
Implementation of Discipline Character Education in Early Childhood (Multi-Site Study in Tunas Bangsa and Aisyiyah Bustanul Athfal Integrated Early Childhood Education at Golf Landasan Ulin)
}

\author{
Laila Mahmudah ${ }^{1 *}$, Asniwati $^{1}$, Aslamiah ${ }^{2}$ \\ ${ }^{1}$ Master Program of Early Childhood Teacher Education, Universitas Lambung Mangkurat, \\ Banjarmasin 70123 Indonesia \\ ${ }^{2}$ Master Program of Education Management, Universitas Lambung Mangkurat, Banjarmasin 70123 \\ Indonesia
}

\section{Article history:}

Submission May 2020

Revised June 2020

Accepted June 2020

${ }^{*}$ Corresponding author:

E-mail: Imahmudah0@gmail.com

\begin{abstract}
The research aims to describe and analyze the Planning, Strategy, and Evaluation of the implementation of disciplined character education in Tunas Bangsa Integrated PAUD and Aisyiyah Bustanul Athfal Golf Integrated Course in Ulin. The results showed: Planning involves foundations, principals, teachers, and education personnel, to formulate policies, set regulations, through meetings, involve parents, and be socialized at the beginning of the school year. Referring to the 2013 Curriculum, 9 pillars of character and $\mathrm{K} 4$ from IHF, training, are integrated in the implementation of learning. Implementation strategy: socialization of regulations, integrated in every lesson. Through habituation, example, protecting attitude, caring, caring, punishment, rewards (consequences), motivation, and consistency. The constraints to its application are in the family and school environment. Evaluation of school regulations by the Foundation, school principals, teachers and educators by identifying problems, deliberations, gathering information, determining solution criteria (follow-up) according to the school's vision, mission, goals. Evaluation of aspects of learning: observation, checklist, daily notes, anecdotes
\end{abstract}

Keywords: character education, discipline character, early childhood

\section{Introduction}

The current quality of education in Indonesia is discouraging. This analysis is in accordance with the various cases of negative behaviors experienced in schools, such as the persecution and killing of teachers by students, violence, bullying, sexual harassment of minors, fights, frequent brawls, disobedience to rules, drug abuse, suicides, and several other cases that became news to the mass media. Some of these act where also carried out by adults that are supposed to act as role models to children.Education is the process of educating, formulating personality, as well as reflecting ethics and aesthetics. Therefore, character-based education needs to be implemented early in order to create integrity in children.
According to Mardiatmadja, characterbased education is the spirit used in harmonizing humans (Majid \& Andayani, 2013). Therefore, it needs to be implemented at every level of education, including early childhood, to create integrity in children.

In connection with some of the abovementioned cases, Suriansyah (2011) stated that character education positively develops the cultural and national values of students, which are implemented to make them religious, nationalist, productive, and creative to the society.

Discipline is related to the ability to obey the rules applicable in a certain group. It is also defined as compliance in various applicable regulations and regularities in daily life. This is applicable in schools by ensuring that

\section{How to cite:}

Mahmudah, L., Asniwati., \& Aslamiah. (2019). Implementation of discipline character education in early childhood (Multi-site study in Tunas Bangsa and Aisyiyah Bustanul Athfal integrated early childhood education at Golf Landasan Ulin). Journal of K6, Education, and Management, 2 (4), 301 - 311. doi: 10.11594/jk6em.02.04.05 
students obey various rules and regulations. One of such rules is by making various positive speaking and behavorial habits.

It is optimal to discipline children at an early age. (Rimm, 2003) stated that discipline immediately children starts crawling or become toddlers, parents need to inculcate maximum discipline. This is inseparable from the support given to family, the environment, and an increase in age. (Morrison, 2012) reported that family involvement is unlimited, however, coordinated efforts are needed to build effective and meaningful programs, capable of providing beneficial educational change for children, professionals, and the community.

According to (Hurlock, 2001), discipline is the behavior of a person that voluntarily learns from a leader. Parents or teachers are leaders, while children are students that learn from them in order to be useful and leave a happy life. In other words, discipline is defined as the strategy used by society to teach children to behave morally.

Discipline character may influence the students' academic achievement (Jung, Zhou, \& Lee, 2017). Those who are more discipline normally have a better academic achievement. The study that was conducted by (Komarraju, Ramsey, \& Rinella, 2013) also found that academic discipline correlates to the students' achievement. In addition, the result of that study also supported by the result of study that was conducted by (Xu, Wang, Peng, \& Wu, 2019) who found that students' discipline behavior, especially in using internet also influence the students' achievement.

(Arteaga, 2015) stated that the key factors in implementing discipline to have a positive impact on student achievement in school were through a clear mission, positive culture, and climate, a harmonious and cohesive model of discipline, and the involvement of all parties.

In connection with this, (Alfiah, 2017) stated that the interaction model in instilling discipline and responsible character in children is through a direct two-way continuous interactive process. There is a good relationship between teachers through the collaborative exchange of opinions to possess the same vision and mission. The relationship between teachers and parents provides adequate information on the development of children's character at home and school.

This helps to shapen the character of students, with the principal's strategy carried out using the philosophy on exemplary, discipline, instructional, and quality leadership, to empower teachers and other educational personnel. The teacher's strategy is exemplary, habituation, and heart touch. Meanwhile, parent and community strategies are effective communication and partnership (Suriansyah \& Aslamiah, 2015).

Based on the above description, this research was conducted on the Implementation of Discipline Character Education in Tunas Bangsa and Aisyiyah Bustanul Athfal Integrated Early Childhood Education at Golf Landasan Ulin.

\section{Material and Methods}

This research used the descriptive qualitative and multi-site approaches. Data were collected from Tunas Bangsa and Aisyiyah Bustanul Athfal Integrated Early Childhood Education at Golf Landasan Ulin, through observation, interview, and documentation.

The data analysis process includes reduction, display, conclusion, and verification. Meanwhile, credibility, transferability, dependability, and conformability were used to check for data validity. In addition, credibility was determined through triangulation, peer checking, and referential adequacy.

\section{Results and Discussion \\ Planning for the Implementation of Disci- pline Character Education}

Planning for the implementation of character education is carried out by formulating school regulatory policies and setting them into rules which are used as a code of conduct that needs to be obeyed by members. This act is carried out by foundations, principals, teachers, and educators with parents mandated for its 
implementation. This activity is carried out at the beginning of the school year.

The code of conduct is the result of meetings between the principal, the board of teachers, and other school officials. During the meeting, the existing rules are considered in accordance with the conditions and environment of the child, with the provision of punishment used as a correction strategy, thereby enabling students to distinguish between right from wrong (Istifadah, 2018).

The code of conduct is a rule arranged in a structured manner for people to implement. When schools are without rules and discipline, they become disorder, irregular, and uncontrolled. Therefore, the application and implementation of school rules help students to be trained and accustomed to living in an organized, responsible, and mature environment (Hadianti, 2008). However, teachers should be really careful in giving punishment, since punishment both corporal and verbal may not really effective means of discipline at schools (Elbla, 2012).

In addition, punishment may be conducted subjectively and it make the students feel that they are not treated equally (Bekkerman \& Gilpin, 2014). Therefore, school punishment links to students' low achievement and school belonging (Gershoff, Sattler, \& Holden, 2019).

Planning is carried out by integrating a disciplined educational character in each child's learning activities based on the 2013 curriculum. This is also integrated with 9 pillars of character and K4 from IHF. Therefore, to prepare teachers to implement it in each activity, training is needed to create semester programs as well as weekly and daily lesson plans such as (RPPM) and (RPPH). The plan includes an annual, semester, weekly, and daily programs. The learning process in an institution is directed with clear guidelines that are outlined in the curriculum. Teachers need to understand the curriculum to implement it in the learning process properly.

There are a variety of good character values implemented to children, with guidelines on the nine pillars of character from Ratna Megawangi and Standards for the
Achievement of Child Development (STTPA) in the 2013 curriculum. The inculcation of character values is implemented in a planned manner and carried out incidentally (Nadlifah, 2017).

Fauzziyah (2011) stated that teachers play the role of planning learning strategies for children in schools. Their roles include the provision and preparation of materials related to the development of children's attitudes and behavior. The teacher needs to provide mapping, syllabus, annual, semester, weekly, and daily programs delivered to students in a timely manner, to achieve the predetermined goal. Things that need to be carried out in planning the character learning instrument are activities to internalize values, with achievement indicators added to achieve changes in student behavior, and techniques for proper character development.

(Suriansyah \& Aslamiah, 2018) stated that the teacher's instruments include discipline and the ability to create a conducive classroom environment capable of shaping students' behavior.

Rules are required as a guideline for proper implementation of discipline. This is formulated through policies involving foundations, principals, teachers, education personnel, and parents' socialization ability at home and the beginning of a school year through WhatsApp, liaison books, and filling out checklist questionnaires.

Furthermore, the success of the management of this program is inseparable from the role of parents and school committees. Therefore, there is an adequate need to establish cooperative relationships to obtain support.

According to Kotaman, active parental involvement tends to provide positive effects on various aspects of education. They improve children's behavior, social adaptation, reduce disciplinary problems, and increases their success and attendance rates to school (Gürbüztürk \& Şad, 2010).

Facilities and infrastructure are provided in a conducive environment, and teachers play a role in facilitating discipline in the school. To enhance discipline, rules are posted on classroom walls and school environments in the form of posters or written 
pamphlets and delivered to students. By using a center method, the teacher prepares and provides a variety of learning media and methods. This superior program is implemented as a form of habituation to support the success of discipline in schools and at home.

The teacher prepares and provides various learning media and methods by implementing character education developed in accordance with the role played by the child. Meanwhile, to improve children development, parents are expected to establish strong communication with teachers and principals (Mafrukha, 2015).

\section{Strategies for the Implementation of Disci- pline Character Education}

The implementation of discipline character education is carried out by school principals, teachers, and educators. The implementation strategy includes parents' ability to socialize the regulations related to learning activities on discipline character education through a liaison book, WhatsApp, and questionnaire. Furthermore, a habituation learning strategy is integrated before and after the principal, teacher, and education staff conducts their educational process with attitudes that protect, love, motivates, pay attention, and directs children.

(Suriansyah \& Aslamiah, 2015) stated that the teacher's strategy in forming character is exemplary, habituation, and heart touching. Meanwhile, the parents and community strategy is effective in accordance with communication and partnership. (Maimunah, Aslamiah, \& Surianyah, 2018). stated that parental involvement in schools in the development of early childhood characters is through building positive communication on a regular basis between teachers, other schools and establishing relationships with other parents to exchange information. Get involved in parenting programs, school committees, teacher meetings with parents, support child development by participating in activities at sentra learning, tourism work, peak themes, religious holidays and national holidays.

According to (Wijaya, 2017), character education strategies in the school environment are carried out through the following strategies: 1 ) regulations regarding the integration of character learning in all subjects, 2) increasing the capacity of schools through teacher training, 3) providing learning resources and 4) awarding educational units that have successfully developed character culture. Meanwhile, the character education strategy in the family environment is carried out through the following strategies: 1) religious determination that encourages parents to interact with schools and educational institutions related to character development, 2) providing training and counseling for character education, 3) giving awards to figures or parents committed in shaping the character of their children in the family environment, and 4) improving communication between schools and related educational institutions with parents.

Imamuddin (2018) stated that there are also exemplary and habituation discipline programs in schools. Furthermore, (Rochimi \& Suismanto, 2018) reported that teachers instill disciplinary values through the following: 1) Exemplary, 2) Habituation, 3) Rewards, and 4) Individual Approach.

The results of study conducted by (Bitasari, 2018) showed that the process of implementing the habituation method in shaping the discipline character of students includes: a.) early character building, b.) dressing neatly and checking student clothing, c.) socialization with parents through social media and meetings when taking report cards, d.) inserting characters in learning, and e.) making class rules. In addition, the efforts made include a.) making and enforcing class rules, b.) putting up school rule boards, c.) conducting discipline evaluation, d.) motivating, and e.) socializing with parents.

It is important to start the formation of a child's character, from an early age, till adulthood. This is because when the right character is instilled from an early age, it clings to them and becomes difficult to change. Therefore, habits are defined as an automatic reaction of a person's behavior to situations that are consistently obtained and manifested repeatedly. An individual that is accustomed to good things has the ability to 
manage themselves properly, thereby, decreasing dependence on others (Wiyono, 2019).

The implementation of discipline character education includes habituation and exemplary activities such as arriving on time to school, being neat and clean, greetings teachers upon arrival, shaking hands with parents, teachers, and principals, putting shoes and bags in their place, reading lqro, performing the Dhuha prayer in congregation, using the game tools properly, orderliness, attending classes regularly, reciting prayers before learning, singing the sya'ir, remembering short surah, orderliness when studying, conducting and completing tasks when given, not seizing friends property, and tidying up each other's books and stationery, It also includes washing hands, and reciting prayers before/after eating, sitting orderly, throwing garbage in its place, using the toilet orderly, etc.

In addition, punishments associated with broken rules are meant to discipline and not frighten students. It is carried out to motivate and appreciate children in the form of support and invitations to discipline. For example, asking children to perform activities that have not been previously conducted, such as throwing garbages away. Teachers act as an example by displaying positive attitudes through the implementation of discipline character, which continuously grows in children until adulthood. Therefore, the school also encourages parents to discipline their children at home to continue the implementation process.

Children need to be accustomed to good habits, to enable their soul to adjust without too much effort and without losing a lot of energy, with limited difficulties. For example, in early childhood, children need to be trained and accustomed to carrying out learning activities, such as waking up early, bathing and sleeping regularly at a certain time, eating foods, etc. Irrespective of their age, the following habits need to implemented, sleeping and waking up at regular times, eating, bathing, playing, talking, learning, working, disposing of children's body waste, etc (Wiyono, 2019).
(Asniwati, 2010) defined control in accordance with the development of the 2013 curriculum-based character education. The principal as the person in charge, viceprincipal, teachers, and school committee, parents, and supervisors. The student code of conduct, and academic regulations explain the lesson plan, the implementation of teaching and learning activities, daily examples, work rules, credit points, documents that form the assessment and supervision team.

(Suriansyah, 2015) reported that habituation is the attitude used to mandate students to carry out activities, such as taking out the trash and putting it in its place, greetings teachers, washing hands after holding trash, etc. Other habits include reading the Qur'an, which is a hallmark of school excellence carried out by remembering the short and long surah, while memorizing the juz. This was proven when a student smoothly read certain verses from the surahs with mistakes. During learning, the teacher trains students to collaborate with other friends, possess adequate courage to express opinions, etc. This habituation strategy is used in an integrated manner in the formation of student character by teachers at all grade levels.

Teachers in carrying out learning inside and outside the classroom always show attitudes, behaviors, and actions that are in accordance with the norms prevailing in schools and communities consistently. In learning activities, the teacher uses polite words to students. Outside the classroom greetings are said when meeting with parents. Students are required to dress following school rules and come to class on time. The teacher also ends the lesson early, shows exemplary clean culture. Therefore, when they start the lesson, each student is asked to look around their respective seats to look for trash, and then throw them in the provided garbage bin provided in the classroom (Suriansyah, 2015).

The findings of this study support the research conducted by (Setyaningrum \& Husamah, 2011), which stated that learning needs to provide an opportunity for students to experience the desired characters directly. 
Character education aims to help students become more morally responsible and disciplined citizens.

The findings of this study are in line with (Arsyad, 2010) research, which reported that the implementation strategy on the formation of attitudes and characters is conducted by habituation, exemplary, heart touch, stories and discipline.

(Suriansyah, 2011) stated that effective partnerships between schools and communities are a form of relationship in organizations and businesses that directly or indirectly aims to improve and develop social/emotional and physical development of children.

(Fatmah, 2017) stated that there are several methods employed by educators in shaping children's character and make them discipline which includes: habituation as a routine, advice by providing warnings or reprimanding them, providing rules for all parties, with the existence of regulations, thereby, making it easier to instill discipline.

The obstacles faced in implementing discipline character include differences of opinion on the regulation policies for the smooth and comfortable learning process. However, the solution is achieved by deliberately reconsidering various aspects related to good discipline. The obstacle in implementing discipline character education is as follows:

1) The family environment: This includes a)The parents' attitude, such as the unconscious instillation of attitudes which affect their character in pampering children, granting all requests without consequences, succumbing to their behavior, understanding their mistakes, not being strict towards rules and inconsistency. b) Parents that are too busy to submit full their responsibility or teachers that are unable to determine the relationships and life lessons received by children. Therefore, it takes a longer period to determine whether the children are properly cared, c) Parents that pay less attention to children make them seek help outside the environment from friends. This is also due to parents' busy working schedule and inability to educate children to be caregivers, and homely, d) Excessive attention from parents inhibits the application of discipline in children. Those that are not strict in educating their children at home make the discipline applied in schools nonoptimal. This category of parents makes their children feel they are too valuable, by over pampering them .2.) School environment, which consists of the following: a) Lack of time in applying the discipline character to children. Most time, this takes a lot of time, with inconsistency and poor sustainably. Meanwhile, cooperation with parents is not optimal, therefore it is important to ensure they pay attention to children at home. Furthermore, the meeting time is only added to the superior program before learning is conducted. b) Children association from basic behaviors with such as the ability to play with others. Therefore, bad associations and non-educative shows influence children's behavior. They carry out activities without thinking of the future effects, while parents, teachers, principals, and educators supervise these activities to avoid, negative effects, and c) Children's self-awareness, where each has a desire for something with their ego capable of affecting their mood, therefore it has an impact on the stability of the child's awareness to obey the rules set.

2) The solution provided by teachers and principals aims to provide understanding and socialization to parents and children, to reflect the discipline character in their daily life and needs. Furthermore, varied learning strategies, such as motivation, punishment, and consequences in teaching, provide appropriate attitudes, appreciation, and consistency in the implementation of discipline character education.

(Cinantya, Suriansyah, \& Asniwati (2018) stated that the supporting factors in implementing character education are parental support, school environment and 
infrastructure, teachers' knowledge and expertise as well as partnerships with outside parties. Some obstacles in the process of character education are lack of support from parents in the form of health and emotional conditions.

Furthermore, the research conducted by (Fatmah, 2017), stated that the inhibiting factor for the implementation of early childhood discipline is the difference in character. The unique character of the child makes the teacher careful in disciplining the child, especially in the condition of a career parent, therefore the time with family is less with lack of consistency in implementing the act.

In order to have a successful program in improving students' discipline, schools schould colaborate with the students' parents. Thre should be a parenting program that educates parents the correct way to promote discipline to the children. It is because not all parents know the best way to discipline their children. The study that was conducted by (Dietz, 2000) shows that the way that parents discipline their children is infulenced by their educational background. Where parents with lower educational background who get viewer resources on good ways of doing discipline to children were more likely to do severe corporal punishment. In addition, parents economic situation also influences their strategy to discipline their children (Theunissen, Vogels, \& Reijneveld, 2015).

In addition, parents belief also influnce they way they discipline their children. The ones who believe that punishmet is a way to discipine children normally give more corporal punishment (Cappa \& Khan, 2011). In terms of pshycological aspect and gender, it is also found that a mother with stress tends to do corporal punishment more than a father (Liu \& Wang, 2018). No matter what the reason is, parents shoud aviod corporal punishment since it will lead to behavioral problems to the children (Fu, Niu, \& Wang, 2019). The study that was conducted by (Grogan-Kaylor, Ma, \& Graham-Bermann, 2018) also found that physical punishment to children will make them possess undisireble behavior and there is a great possibility that they will do the same to their children in the future. Therefore, school should help parents through parenting program in changing their attitude toward corporal punishment in order to prevent it and decrease its use (Xing, Wang, Wang, \& Wang, 2019).

Violent discipline will bring harmful effects on child development, especially on their behavior development (Wolf \& Suntheimer, 2020). Therefore, it is suggested that school teachers use logical consequences than punishment since logical consequences work beter to shape students' discipline (Mageaua, et al., 2018).

The factors influencing the discipline of children in Play Group or Kindergarten of Pedagogia are consistency, footing, reward and punishment, children's understanding of regulations, parental education, socioeconomic status, and family. The supporting factor for discipline habituation of children is punishment, while the inhibiting factor is consistency (Lukitasari, 2017). To overcome these factors, teachers carry out parenting, social media support groups, and communicate directly with parents. Discipline habituation in the Play Group or Kindergarten of Pedagogia is a democratic and authoritarian discipline. As a result, children are disciplined in terms of obeying rules and regulations, managing time, or self-control.

The obstacles associated with parents are in the form of inconsistencies in carrying out or implementing rules (Guntur, 2018). Sometimes parents are less consistent in instilling the moral value of discipline. Based on the conclusion, the inhibiting factor is the unlimited freedom for children to act and behave in their own accord.

\section{The evalution of Discipline Chacacter Ed- ucation Implementation}

After compiling the planning and implementation of the discipline character education strategy, evaluation is carried out using observations, checklists, daily notes, and anecdotal notes. The assessment is conducted during the learning period and outside the classroom to determine the success of the regulations on the programs and activities carried out during the school year. 
The assessment process is an inseparable part of learning that is holistic in nature, covering all aspects of student development both in attitudes, science, and skills (Zahro, 2015). For the assessment objectives to be achieved, the teacher needs to possess adequate knowledge of various assessment methods and techniques considered most appropriate to the objectives and learning process. In daily learning activities, the use of various assessment techniques is integrated. Some assessment techniques carried out in Early Childhood Education include Observation, recording, and documenting children's development and learning outcomes by using daily, anecdotal, and work notes.

Early Childhood Education needs to use a special approach in conducting assessments, this is because it consists of different development characteristics compared to elementary and middle school-age children (Hani, 2019). Therefore, teachers need to make adjustments to the way of observation of each learning evaluation with the Daily
Learning Plan (RPPH) that is used, such as anecdotal and running records, checklist, time, and sampling events .

The evaluation of regulatory policies is carried out by the foundation with school principals, teachers, and educators once a year through internal meetings. This is carried out by identifying problems, conducting meeting, gathering information to be able to improve regulations that have not been maximized together, and in determining the criteria for solutions through follow-up by involving all parties, such as the foundation, principal, teachers, and education staff, as well socializing by parents.

Evaluations such as the assessments and controls are conducted by teachers towards an assessment of attitudes to their students (Nuriyatun, 2016). Furthermore, the problems found are discussed with the teacher, principal, and students' guardians. To achieve a successful evaluation, the school involves student guardians to control them outside the learning environment.

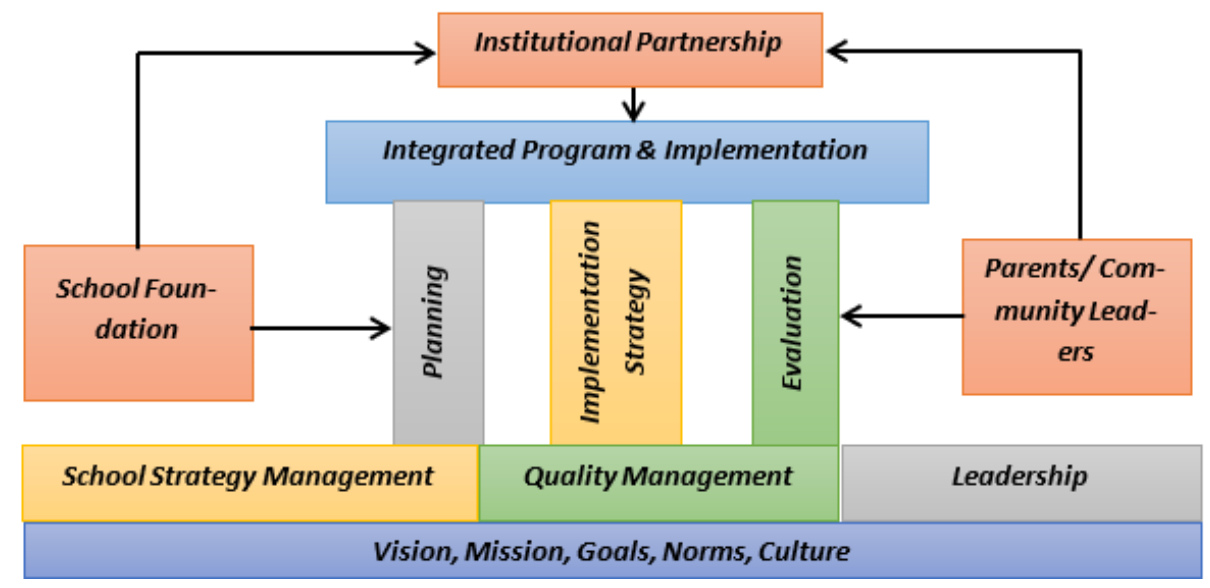

Figure 1. Final scheme findings implementation of disciplinary character education in PAUD integrated Tunas Bangsa and integrated PAUD Aisyiyah Bustanul Athfal Golf Landasan Ulin

\section{Conclusion and Recommendation}

In conclusion, planning in Tunas Bangsa and Aisyiyah Bustanul Athfal Integrated Early Childhood Education at Golf Landasan Ulin is carried out by involving foundations, principals, teachers, and education staff, by formulating regulatory policies and setting regulations, of the 2013 Curriculum. Furthermore, the 9 pillars of character, $\mathrm{K} 4$ from the IHF, and conducting discipline character education training integrated into the learning implementation plan (RPPM \& RPPH) are utilized. It also involves parents by socializing school rules at the beginning of the school year and delivering questionnaire instruments on student discipline. 
The implementation of disciplined character education is carried out by school principals, teachers, and education personnel. The implementation strategy consists of the Socialization of rules in an integrated manner with habituation and exemplary behavior that displays an attitude of protection, love, and care. The existence of punishment and rewards by providing motivation is carried out consistently. The implementation strategy is also carried out by involving parents through a contact book, WhatsApp, and checklist instruments. The implementation of discipline character is carried out from the beginning till the end of the learning process. The constraints in applying discipline character education occur in the family and school environment.

The evaluation of school regulation policies is conducted by foundations, school principals, teachers, and educators by identifying problems, deliberations, gathering information, and determining solution criteria through follow-up. Discipline character evaluation is conducted by observation, checklist, daily notes, and anecdotal notes.

\section{Acknowledgment}

The author is grateful to the principal and teachers that helped to smooth the research process.

\section{References}

Alfiah, A. (2017). Analysis of inculcation of discipline character and responsibility in Kindergarten Aisyiyah Bustanul Athfal Semarang. Semarang: Postgraduate Semarang State University.

Arsyad, A. (2010). Strategies for implementing national character education in tertiary institutions. National Seminar on Nation Character Education. Bogor: Balitbangdiknas.

Arteaga, S. L. (2015). A Program evaluation of what factors influence the implementation of discipline as it relates to a low performing alternative school in Southeastern North Carolina. East Carolina: East Carolina University.

Asniwati. (2010). Primary school management in developing curriculum-based character education 2013). Malang: Malang University.

Bekkerman, A., \& Gilpin, G. A. (2014). Can equitable punishment be mandated? Estimating impacts of sentencing guidelines on disciplinary disparities.
International Review of Law and Economics, 40, 51-61. doi:https://doi.org/10.1016/j.irle.2014.09.002

Bitasari, W. (2018). Implementation of habituation methods in shaping the discipline character of fourth grade students in Brawijaya Smart School elementary. Malang: Maulana Malik Ibrahim State Islamic University of Malang.

Cappa, C., \& Khan, S. M. (2011). Understanding caregivers' attitudes towards physical punishment of children: Evidence from 34 low- and middle-income countries. Child Abuse \& Neglect, 35(12), 1009-1021. doi:https://doi.org/10.1016/j.chiabu.2011.10.003

Cinantya, C., Suriansyah, A., \& Asniwati. (2018). The model of religion-based character education (Multi-site integrated Islamic PAUD sabilal muhtadin and PAUD Islam Mawaddah Banjarmasin, Indonesia). European journal of education studies, 5(7), 1-13. doi:10.5281/zenodo. 1494158

Dietz, T. L. (2000). Disciplining children: characteristics associated with the use of corporal punishment. Child Abuse \& Neglect, 24(12), 1529-1542. doi:https://doi.org/10.1016/S0145-2134(00)00213-1

Elbla, A. I. (2012). Is Punishment (corporal or verbal) an effective means of discipline in schools?: case study of two basic schools in greater Khartoum/Sudan. Procedia - Social and Behavioral Sciences, 69, 1656-1663. doi:https://doi.org/10.1016/j.sbspro.2012.12.112

Fatmah, N. A. (2017). The pattern of application of early childhood discipline in TK Kamala Bhayangkari 05 Sleman. Yogyakarta: Sunan Kalijaga Islamic University.

Fu, C., Niu, H., \& Wang, M. (2019). Parental corporal punishment and children's problem behaviors: The moderating effects of parental inductive reasoning in China. Children and Youth Services Review, 99, 1-9. doi:https://doi.org/10.1016/j.childyouth.2019.01.028

Gershoff, E., Sattler, K. M., \& Holden, G. W. (2019). School corporal punishment and its associations with achievement and adjustment. Journal of Applied Developmental Psychology, 63, 1-8. doi:https://doi.org/10.1016/j.appdev.2019.05.004

Grogan-Kaylor, A., Ma, J., \& Graham-Bermann, S. A. (2018). The case against physical punishment. Current opinion in psychology, 22-27. doi:https://doi.org/10.1016/j.copsyc.2017.03.022

Guntur, N. A. (2018). The role of parents in instilling children's discipline in the village of Kalimporo. Makassar: Makassar State University.

Gürbüztürk, O., \& Şad, S. N. (2010). Turkish parental involvement scale: validity and reliability studies. Procedia - Social and Behavioral Sciences, 2(2), 487491. doi:https://doi.org/10.1016/j.sbspro.2010.03.049 
Hadianti, L. S. (2008). The influence of the implementation of school discipline on student learning discipline (descriptive analysis research at SDN Sukakarya II, Samarang District, Garut Regency). Jurnal Pendidikan Universitas Garut, 2(1), 1-8.

Hani, A. A. (2019). Evaluasi pembelajaran pada PAUD. Jurnal CARE, 7(1), 1-6.

Hurlock. (2001). Child Development. New Delhi: McGraw-Hill Education.

Imamuddin, M. (2018). The influence of the implementation of school discipline on student learning discipline (Descriptive analysis research at SDN Sukakarya II, Samarang District, Garut Regency). Surakarta: Institut Agama Islam Negeri Surakarta.

Istifadah, S. Y. (2018). Rules of discipline in early childhood education (PAUD) As Shofiyah Kedungrejo. Yogyakarta: Sunan Kalijaga State Islamic University.

Jung, K.-R., Zhou, A. Q., \& Lee, R. M. (2017). Self-efficacy, self-discipline and academic performance: Testing a context-specific mediation model. Learning and Individual Differences, 60, 33-39. doi:https://doi.org/10.1016/j.lindif.2017.10.004

Komarraju, M., Ramsey, A., \& Rinella, V. (2013). Cognitive and non-cognitive predictors of college readiness and performance: Role of academic discipline. Learning and Individual Differences, 24, 103-109. doi:https://doi.org/10.1016/j.lindif.2012.12.007

Liu, H. N., \& Wang, M. (2018). Intergenerational transmission of harsh discipline: The moderating role of parenting stress and parent gender. Child Abuse \& Neglect, 79, 1 10. doi:https://doi.org/10.1016/j.chiabu.2018.01.017

Lukitasari, S. (2017). Description of discipline of children aged 5-6 years in Playgroup / Kindergarten. Yogyakarta: Universitas Negeri Yogyakarta.

Mafrukha, H. (2015). Descriptive study of the application of character education at role play center of Smart Children Play Group. Semarang: Universitas Negeri Semarang.

Mageaua, G. A., Lessarda, J., Carpentier, J., Robichaud, J.M., Joussemet, M., \& Koestner, R. (2018). Effectiveness and acceptability beliefs regarding logical consequences and mild punishments. Journal of Applied Developmental Psychology, 54, 12-22. doi:https://doi.org/10.1016/j.appdev.2017.11.001

Maimunah, Aslamiah, \& Suriansyah, A. (2018). The integration of sentra-based learning and involvement of family program at early childhood in developing character building. European Journal of Education Studies, 5(7), 49-62. doi:10.5281/zenodo.1494207

Majid, A., \& Andayani, D. (2013). Pendidikan karakter perspektif Islam (Islamic perspective character education). Bandung: Remaja Rosdakarya.
Morrison, G. S. (2012). Basics of early childhood education. Jakarta: Indeks.

Nadlifah. (2017). An integrated holistic character education development model in An-Nur Sleman Early Childhood Education. Journal of Children's Education, 3 (1), 1-8.

Nuriyatun, P. D. (2016). Implementation of discipline and responsibility character education in SD Negeri 1 Bantul. Journal of Primary School Teacher Education, 33(5), 18.

Rimm, S. (2003). Educate and apply discipline to preschool children. jakarta: Gramedia Pustaka Utama.

Rochimi, I. F., \& Suismanto. (2018). Teachers' efforts to instill the values of discipline in early childhood. Scientific Journal of Early Childhood Development, 3(4), 231-246.

Setyaningrum, Y., \& Husamah. (2011). Optimizing the application of character education in secondary schools based on process skills: A biological science teacher perspective. Jurnal Penelitian Dan Pemikiran Pendidikan, 1(1), 69-81.

Suriansyah, A. (2011). Character education in the perspective of the national education system. Journal of Education, 6(11), 117-130.

Suriansyah, A. (2015). Management of school resources with the community in the context of community empowerment. Jakarta: Rajawali Press.

Suriansyah, A., \& Aslamiah. (2015). Leadership strategies of school principals, teachers, parents and the community in shaping the character of students. Cakrawala Pendidikan Scientific Journal of Education, 34(2), 234247. doi:https://doi.org/10.21831/cp.v2i2.4828

Suriansyah, A., \& Aslamiah. (2018). Teacher's job satisfaction on elementary school: Relation to learning enveronment. Open Psichology Journal, 11, 123-130. doi:10.2174/1874350101811010123

Theunissen, M. H., Vogels, A. G., \& Reijneveld, S. A. (2015). Punishment and reward in parental discipline for children aged 5 to 6 years: Prevalence and groups at risk. Academic Pediatrics, 15(1), 96-102. doi:https://doi.org/10.1016/j.acap.2014.06.024

Wijaya, D. (2017). Culture and national character education for schools and colleges. jakarta: Mitra Wacana Media.

Wiyono, B. B. (2019). Capita selekta of education: incandescent thinking about concepts, systems, and problems of education in Indonesia. Malang: State University of Malang.

Wolf, S., \& Suntheimer, N. M. (2020). Predictors of parental disciplinary practices and associations with child outcomes among Ghanaian preschoolers. Children and Youth Services Review, 112, 1-16. doi:https://doi.org/10.1016/j.childyouth.2019.104518 
Xing, Y., Wang, M., Wang, Y., \& Wang, F. (2019). Exploring the reciprocal relations between mothers' and fathers' use and attitudes of corporal punishment in China: A cross-lagged analysis. Child Abuse \& Neglect, 88, 171178. doi:https://doi.org/10.1016/j.chiabu.2018.11.006

Xu, X., Wang, J., Peng, H., \& Wu, R. (2019). Prediction of academic performance associated with internet usage behaviors using machine learning algorithms. Computers in Human Behavior, 98, 166-173. doi:https://doi.org/10.1016/j.chb.2019.04.015

Zahro, I. F. (2015). Assessment in early childhood learning. Tunas Siliwangi: Journal of Early Childhood Education teacher education courses, 1(1), 92-111. doi:https://doi.org/10.22460/ts.v1i1p92-111.95 